\title{
EXPLORING THE USE OF PEER-MEDIATED INSTRUCTIONAL STRATEGY IN EFL READING CLASSROOM
}

\author{
Trisilia Devana, Merie Agustiani, M. Pd.*) \\ (Email:dtrisilia@yahoo.co.id), (Email: merieagustiani@gmail.com) \\ Pendidikan Bahasa Inggris \\ Universitas Baturaja, Palembang
}

\begin{abstract}
Abstrak
Peer-mediated instruction strategy adalah intervensi kelas yang memberikan bantuan antar para siswa. Diyakini bahwa peer-mediated instruction strategy dapat meningkatkan hasil akademik, sosial, dan komunikasi bagi para siswa. Tujuan dari penelitian ini adalah untuk mengetahui efektivitas Peer-mediated instruction strategy dalam meningkatkan kemampuan pemahaman membaca siswa. Penelitian ini dilakukan di SMAN 5 OKU dan diikuti oleh enam puluh tiga siswa yang dipilih melalui teknik purposive sampling. Selanjutnya, 30 pertanyaan pilihan ganda digunakan dalam tes membaca pemahaman dan uji-t digunakan untuk mengetahui apakah Peer-mediated instruction dapat membuat perbedaan yang signifikan terhadap pencapaian pemahaman membaca siswa. Hasil penelitian menunjukkan bahwa baik CWPT dan PALS, sebagai dua model Peer-mediated instruction strategy, efektif digunakan sebagai alternatif strategi pembelajaran membaca.
\end{abstract}

\section{Kata kunci: Peer-mediated instruction, CWPT, PALS, tutor, tutee}

\section{INTRODUCTION}

Reading is one of the ways of learning process for the students to get knowledge and skills. This becomes very essential since it is the foundation for the students to explore their productive skills. Romero, Angelita, Romero and Rene (2008) explain that reading is a process of communication between author and reader. Reading is the ability of the students to get the information of the written language. It means that, the students use their ability to get the information that available in the text. Nunan (2006) points that reading comprehension refers to reading for meaning, understanding, and entertainment. It means that reader as well as analyzes what they had read were an essential part of reading process. The readers had to read the text correctly because without comprehension, the reader did not understand that they had read. Improving students' comprehension in reading is not only giving and remembering words with their meaning, but also help them to develop the concept of words based on their knowledge. Conceptual knowledge of words will help students in making 
prediction before reading text, setting purpose for reading, building vocabulary knowledge and understanding text passage. Developing the conceptual knowledge of words means that students are able to identify, category and label the words that they had in their mind to a concept that related.

Teaching reading is not only to learn about read aloud the text but the students have to comprehend all of the elements of the text and can get information in the text. Further, teaching and learning reading has been arranged in school base on curriculum but in fact, it is still disregarded. Many students did not have a motivation in learning reading lesson; they think that reading was monotone and boring activity. In addition, they prefer to read Indonesia text to English text because Indonesia text was easier to understand. Due to this habit, students' English reading competence and achievement would not be good enough. Students need a comfortable and motivating classroom in order to get the students enjoy the reading class. The choice of appropriate teaching methodology will absolutely give impact to students' progress.

Peer-mediated instruction is a collaborative learning strategy which is believed can help and motivate the students in reading classroom. Bell and Carter (2013) point out that Peer-mediated instruction support strategies involve one or more peers providing assistance among students. Peer-mediated instruction, which is also well known as peer tutoring learning strategy, is believed promote academic, social, and communication outcomes for the students (Rahmasari, 2017; Hott and Walker, 2012). Rahmasari (2017) explains that peer tutoring is a type of instructional strategy in which students are taught by their peers, who have been trained and supervised by the classroom teacher. Peer tutoring involves having students work in pairs, with another student of the same age or grade. Peer-mediated refers to a wide variety of intervention approaches. Some of those intervention approaches are Class Wide Peer Tutoring (CWPT), Cross-Age Peer Tutoring (CAPT), Reciprocal Peer Tutoring (RPT) and Peer Assisted Learning Strategies (PALS). Therefore, this study was aimed at exploring the use of CWPT and PALS as peer tutoring models.

\section{LITERATURE REVIEW}

\section{Reading Comprehension}

Alyousef (2005) mentions that reading can be seen as an "interactive" process between a reader and a text which leads to automaticity. In this process, the reader interacts dynamically with the text as he/she tries to elicit the meaning and where various kinds of knowledge are being used: linguistic or systemic knowledge (through bottom-up 
processing) as well as schematic knowledge (through top-down processing). Snow (2002) describes that reading comprehension as the process of simultaneously extracting and constructing meaning through interaction and involvement with written language. In addition, According Linse (2005, p.71) reading comprehension refers to reading for meaning, understanding, and entertains; it involves higher-order thinking skills and is much more complex than merely decoding specific word.

\section{Peer-Mediated Instructional Strategy}

Peer-mediated instructional strategy began in the late of 1700s by Andrew Bell as an alternative of teacher directed instruction. Furthermore, peer-mediated instructional strategy is classroom intervention that provides assistance among the students. It is an effective alternative to the use of one-to-one paraprofessionals in classrooms, clubs, and other school activities (Bell and Carter, p.2013). Kapil and Malini (2018) mentions that there are fve benefits of peer-mediated teaching; (1) increased literacy score, (2) developed reasoning and critical thinking skills, (3) improved confidence and interpersonal skills, (4) increased confort and openness, and (5) versality.

There are many different ways that teacher can choose to pair the students. It can be based on their ability level, skills mastered, or age. The following description is about two models of peer-mediated instruction that can be chosen by the teachers:

\section{Class Wide Peer Tutoring (CWPT)}

Kapil and Malini (2018) Class Wide Peer Tutoring (CWPT) involves dividing the entire class into groups of two to five students with different ability levels. Students then act as tutors, tutees, or both and tutees. Further, while the procedures and routines in CWPT remain the same, student pairings or groups may change weekly or biweekly. In CWPT, student pairings are fluid and may be based on achievement levels or student compatibility. In class wide peer tutoring, every student in the class belongs to a group and has the opportunity to get one-on-one help while students in a group alternate roles in reciprocal peer tutoring (Mkpanang, 2016).

\section{Peer Assisted Learning Strategies (PALS)}

PALS is a version of the CWPT model, involves a teacher pairing students who need additional instruction or help with a peer who can assist (Fuchs, Fuchs, \& McMaster, 2006). The pairs are changed regularly, giving all students the opportunity to act as coaches and players. Students are paired with students around 
the same ability level (without a large discrepancy between abilities). The tutee and tutor roles can change based on which student needs help on a particular skill. For example, one student may help his partner with science vocabulary words, and then the partner may change roles and help the other student with multiplication facts (Kapil and Malini, p.2017).

\section{METHODOLOGY}

This experimental study was conducted through quasi-experimental design. The population of this study was all of the tenth graders of SMAN 5 OKU. In selecting the sample of the study, purposive sampling technique was used. There were 63 of tenth graders who were chosen on the basis of their ability level that the researchers got from the achievement records of the English teacher at the school. There were 32 students assigned to CWPT group and 30 students assigned to PALS group.

Reading comprehension achievement that consists of 30 multiple questions was used in collecting the data and administered to 32 non-sample students. Validity and reliability of reading Ccomprehension test were measured through SPSS 21.The result showed that the cronbach alpha value was 0.82 , meaning that the test was reliable. The question items were also valid since the correlation values of the items were higher than $\mathrm{r}_{\text {Table }}(0.3388)$.

Furthermore, t-test was used to analyze the data in order to find the significant difference of reading comprehension achievement both the students in CWPT and PALS group.

\section{RESULT AND DISCUSSIONS}

\section{Result}

Descriptive Analysis

In PALS group, the students mean score of pre-test was 55.56. in pre-test there was no students in excellent criteria, 3 students $(9,3 \%)$ in good criteria, 7 students $(21,87 \%)$ average criteria, 8 students $(25 \%)$ in poor criteria and 14 students $(43,75 \%)$ in fail criteria. Meanwhile, the mean score of post-test was 76.26. In post-test, there were 14 students $(46,6 \%)$ in excellent criteria, 7 students $(23,4 \%)$ in good criteria, 6 students (20\%) in average criteria, and 3 students $(10 \%)$ in poor criteria.

In CWPT group, the students mean score of pre-test was 46.50 and the mean score of pos-test was 69.5. There were 3 students $(9.37 \%)$ in good criteria, 7 students $(21.8 \%)$ in average category, 8 students $(25 \%)$ in poor category, and 14 students $(43.75 \%)$ in fail category. Meanwhile in post-test, there were 5 students $(15.62 \%)$ in excellent category, 15 students (46.87\%) in good category, and 12 students (37.5\%) in average category. 
The distribution of pre-test and postgroups were presented in table 1. test scores, both in PALS and CWPT

Table 1. Distribution of Pre-test and Post-test Scores

\begin{tabular}{cccccc}
\hline \hline \multirow{2}{*}{$\begin{array}{c}\text { Score } \\
\text { Interval }\end{array}$} & \multirow{2}{*}{ Criteria } & \multicolumn{2}{c}{ PALS Group } & \multicolumn{2}{c}{ CWPT Group } \\
\cline { 3 - 6 } & & Pre-test & Post-test & Pre test & Post-test \\
\hline \hline $80-100$ & Excellent & $1(3.33 \%)$ & $14(46.6 \%)$ & - & $5(15.62 \%)$ \\
$66-79$ & Good & $5(16.66 \%)$ & $7(23.4 \% 0$ & $3(9.37 \%)$ & $15(46.87 \%)$ \\
$56-65$ & Average & $8(26.66 \%)$ & $6(20 \%)$ & $7(21.87 \%)$ & $12(37.5 \%)$ \\
$46-55$ & Poor & $6(20 \%)$ & - & $8(25 \%)$ & - \\
$0-45$ & Fail & $10(33.33 \%)$ & $3(10 \%)$ & $14(43.75 \%)$ & - \\
\hline \hline & TOTAL & $\mathbf{3 0 ( 1 0 0 \% )}$ & $\mathbf{3 0 ( 1 0 0 \% )}$ & $\mathbf{3 2 ( 1 0 0 \% )}$ & $\mathbf{3 2 ( 1 0 0 \% )}$ \\
\hline \hline
\end{tabular}

Statistical Analysis

Before doing the statistical analysis, normality and homogeneity tests were computed using Kolmogorov-Smirnov test and Levene statistics test to ensure the data were normal and homogenous.

The results of normality and homogeneity tests were presented in table 2 .

Table 2. The Results of Normality and Homogeneity Tests

\begin{tabular}{cccc}
\hline \hline Groups & $\mathbf{N}$ & Homogeneity & Normality \\
\hline \hline PALS & 60 & 0.239 & 0.812 \\
CWPT & 64 & 0.844 & 0.342 \\
\hline \hline
\end{tabular}

Further, t-test was computed through SPSS 21 to find out the effectiveness of using PALS and CWPT as two models of Peer-mediated Instruction Strategies. The result of paired sample t-tests revealed that both PALS and CWPT were effective to use in reading classroom. It was obtained that mean difference between pretest and postest was 20.667 and the significant value was 0.00 whis means that there were significant improvement of achievement after the intervention using PALS. In addition. In CWPT groups, the mean difference between pretest and postest was 23.00 and the significant value was also 0.00 .

The result of independent t-test showed that mean difference of postest scores between PALS and CWPT groups was 6.76 and the significant value was 0.28 , 
meaning that PALS has more significant comprehension achievement. The result of impact toward the students' reading t-tests were shown in table 3.

Table 3. The Results of t-tests in PALS and CWPT Groups

\begin{tabular}{|c|c|c|c|c|c|c|c|c|c|}
\hline \multicolumn{4}{|c|}{ Mean score } & \multirow{3}{*}{$\begin{array}{c}\text { Mean } \\
\text { dif } \\
\text { Within } \\
\text { the } \\
\text { groups } \\
\text { (PALS) }\end{array}$} & \multirow{3}{*}{$\begin{array}{c}\text { Mean } \\
\text { dif } \\
\text { Within } \\
\text { the } \\
\text { groups } \\
\text { (CWPT) }\end{array}$} & \multirow{3}{*}{$\begin{array}{l}\text { Mean dif of } \\
\text { post-test } \\
\text { score } \\
\text { Between } \\
\text { the groups }\end{array}$} & \multirow{3}{*}{$\begin{array}{l}\text { T obtained } \\
\text { Within } \\
\text { the } \\
\text { group/ } \\
\text { Sig. value } \\
\text { (PALS) }\end{array}$} & \multirow{3}{*}{$\begin{array}{c}\mathbf{T}_{\text {obtained }} \\
\text { Within } \\
\text { the } \\
\text { group/ } \\
\text { Sig. value } \\
\text { (CWPT) }\end{array}$} & \multirow{3}{*}{$\begin{array}{c}T_{\text {obtained }} \\
\text { between } \\
\text { the } \\
\text { group/sig. } \\
\text { Value }\end{array}$} \\
\hline & $\mathbf{L S}$ & & & & & & & & \\
\hline Pre & Post & Pre & 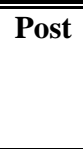 & & & & & & \\
\hline 55.56 & 76.26 & 46.5 & 69.5 & 20.667 & 23.0 & 6.76 & $\begin{array}{r}26.072 \\
\mathbf{0 . 0 0}\end{array}$ & $\begin{array}{r}10.188 \\
\mathbf{0 . 0 0}\end{array}$ & $\begin{array}{r}2.245 \\
\mathbf{0 . 2 8}\end{array}$ \\
\hline
\end{tabular}

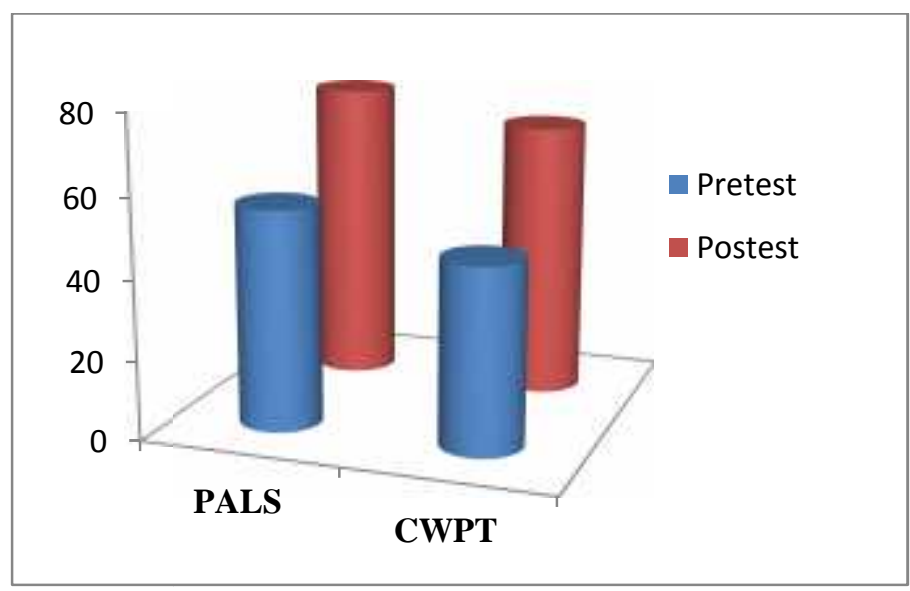

Chart 1. Mean difference of pre-test and post-test scores

\section{Discussions}

Referring to the findings above, it can interpreted that Peer-Mediated Instruction strategies were beneficial in EFL reading classroom. This finding was similar with other finding of researchers who concerned on finding the right formula to increase the students' reading comprehension acheivement. Ryan, Pierce, and Mooney (2008) reported that peer-mediated intervention in the classroom demontstrated strongly positive findings relative to improving academic performance. Further, following 8 weeks of peer-tutoring sessions that lasted appoximately 30 minutes per day, both the tutors and the tutees showed greater increases in both sight words and positive social interactions than did their classmates who had not participated in peer tutoring.

Bombardelli (2016) explains that in peer-mediated instruction, students learn from their peers reaching higher learning and greater retention in the considered 
educational/subject areas through without a large discrepancy between individualized attention, closeness with the abilities (Kapil \& Malini, 2018). An Ohio instructor, influence of a role model. University pilot study that reported in Kapil Students significantly enhance collaborative learning experience, learn to listen to others, improve social interaction and language development.

Through CWPT the students are able to organize their ideas about the text they have read by their own schema and it supports a cooperative learning environment. While working in classwide peer tutoring, students practice cooperation and compromise as they share ideas to create and express one powerful idea. Further, PALS, which is a version of CWPT, gives the students opportunity to function as tutor or tutee at different times. Students are typically paired with other students who are at the same skill level, and Malini (2018) revealed that students who read and discuss story passages with their peers recall more content and score higher assessment.

\section{CONCLUSION}

Peer-mediated instructional strategy were designed in EFL reading classroom, in which more skilled readers were paired with less skilled readers in a routine of peer modelling and feedback.

It is an instructional strategy that is not only reading classroom but also other kinds of academic areas. It is a strategy that can be adapted to meet individual students' needs. Besides, it gives the students opportunity to engage in social interactions.

\section{REFERENCES}

Alyousef, H. S. (2005). Teaching reading comprehension to ESL/ EFL learners. The Reading Matrix, 5(2), 144.

Bombadelli, O. (2016). Effective teaching practice: Peer tutoring in education for active citizenship. International Conference on Education and Educational Psychology. eISSN: 2357-1330.

Bell, L. \& Carter, E.W. (2013). Peer-mediated support strategies. Retrieved from https://vkc.mc.vanderbilt.edu/assets/files/resources/psiPeermedstrategies.pdf

Hot, B. and Walker, J. (2012). Peer tutoring. Retrieved from https://council-for-learningdisabilities.org/wp-content/uploads/2013/11/Peer-Tutoring.pdf

Kapil, Y. \& Malini, S.J. (2018). Peer tutoring an instructional strategy: A systematic approach. Scholarly Research Journal for Humanity Science and English Languange,6(27), 7792-7798. 
Linse, C.T. (2005). Practical English language teaching: young learner. New York: McGraw Hill.

McMaster, K.L, Fuchs, G., Fuchs, L.S. (2006). Research on peer-assisted learning strategies: The promise and limitation of peer-mediated instruction. Reading and Writing Quarterly, 22, 5-25.

Mkpanang, J.T. (2016). Effects of class wide and reciprocal peer tutoring strategies on students' Mathematical problem solving achievement in electricity concepts in physics. International Journal of Education, Learning and Development, 4(3), 37-44.

Nunan, D. (2006). Teaching reading skill in foreign languange. Oxford: Heineman International publising Company.

Rahmasari, B.S. (2017). Peer tutoring: An effective technique to teach reading comprehension. The 4th International Conference on Language, Society and Culture in Asian Contexts, KnE Social Sciences, 245-258. DOI 10.18502/kss.v1i3.745

Romero, D., Angelita, \& Romero, C., Rene (2008). Developmental reading. A skill text for collage students. Quazon City: Rex Book Store.

Ryan, J.B., Piercs, C.D., \& Mooney, P. (2008). Evidende-based teaching strategies for students with EBD. Retrieved from https://www.mona.uwi.edu/cop/sites/default/files/resource/files/evidenced\%20based\% 20teachins\%20strategies\%20-EDC.pdf

Snow, C. E. (2002). Reading for understanding (towards an $R \& D$ program in reading comprehension). Santa Monica: RAND. 